\title{
Diagnosztikus lépések és a betegség prognózisának becslése COVID-19-fertőzött betegeken
}

\author{
Korsós Anita dr. - Kupcsulik Szilvia dr. \\ Lovas András dr. - Hankovszky Péter dr. - Molnár Tamás dr. \\ Szabó Zsolt dr. - Babik Barna dr.
}

Szegedi Tudományegyetem, Általános Orvostudományi Kar, Aneszteziológiai és Intenzív Terápiás Intézet, Szeged

2019 decemberében új koronavírus okozta járvány ütötte fel a fejét a kínai Wuhanban. Az azonosított kórokozó egy új koronavírus, melyet „severe acute respiratory syndrome coronavirus 2"-nek, azaz SARS-CoV-2-nek neveztek el, az általa kiváltott légzési tünetegyüttes pedig a „coronavirus disease 2019”, azaz COVID-19 nevet kapta. Az Egészségügyi Világszervezet (WHO) a járványt 2020 márciusában pandémiává minősítette. Áttekintettük a jelenleg elérhető nemzetközi irodalmat a COVID-19-járvány vonatkozásában. Írásunkban az új koronavírus diagnosztikájára és prognosztikájára vonatkozó releváns információkat összegezzük. Részletezzük a klinikai gyanú felvetéséhez szükséges anamnesztikus tényezőket és kezdeti vizsgálati eredményeket, a mikrobiológiai mintavétel módját, a molekuláris diagnosztikai tesztre - az arany standardnak minősülő 'real-time' reverztranszkriptáz polimeráz-láncreakcióra (RT-PCR) - vonatkozó alapvető információkat, különös tekintettel a diagnosztikus tesztelést érintő, jelenleg érvényben lévő népegészségügyi szabályozásra. Hangsúlyt fektetünk továbbá a nagy rizikójú betegek paramétereire és felismerésük módjára. A COVID-19-pandémia Magyarországon is jelentős járványügyi és egészségügyi következményekkel járhat. A járvány lassítására irányuló epidemiológiai intézkedéseken túl a már fertőzött személyek időbeli felismerése és megfelelő kórházi ellátása mortalitási szempontból is kulcskérdés. A kritikus állapotú betegek esélyeit csak magas minőségü, körültekintő intenzív terápiás ellátással lehet javítani, s hogy a legjobbat tudjuk nyújtani, hasznos, ha felhasználjuk a már endémiás országokban dolgozó orvoskollégák tapasztalatait.

Orv Hetil. 2020; 160(17): 667-671.

Kulcsszavak: járvány, pandémia, új koronavírus, SARS-CoV-2, COVID-19, diagnosztika, RT-PCR, magas rizikójú beteg, prognózis

\section{Diagnostic consideration and bedside estimation of the prognosis in COVID-19 patients}

In December 2019, a cluster of pneumonia cases of unknown origin occured in Wuhan, China. The identified infective agent is a novel corona virus called "severe acute respiratory syndrome coronavirus 2" (SARS-CoV-2) and the respiratory disease caused by this agent aquired the name "coronavirus disease 2019" (COVID-19). In March 2020, the World Health Organization (WHO) declared the novel coronavirus outbreak a pandemic. We reviewed the international literature regarding the novel coronavirus outbreak. Here below, we focus mainly on the diagnostic issues of COVID-19 and on the estimation of the prognosis. We detail the relevant anamnestic factors and initial examination results which serve as basics for the clinical suspicion of COVID-19. We also focus on the proper method of microbiological sampling and the relevant informations regarding diagnostic tests like the gold standard real-time reverse transcriptase polymerase chain reaction (RT-PCR) for SARS-CoV-2. We also cite the current national epidemiologic regulations of testing for novel coronavirus. In the last section, we emphasize the importance and the potential way of early identification of high-risk patients. The COVID-19 pandemic may cause substantial epidemiological and healthcare burden even in Hungary. In addition to the epidemiologic interventions aiming the deceleration of the outbreak, the early identification and the correct hospital treatment remain key issues since these may influence mortality. The chances of the critically ill patients could be improved solely by a high-quality and careful critical care. It is prudent to meet the experiences of colleagues working hard with these patients in the already heavily infected countries. 
Keywords: outbreak, pandemic, novel coronavirus, SARS-CoV-2, COVID-19, diagnostic testing, RT-PCR, highrisk patient, prognosis

Korsós A, Kupcsulik Sz, Lovas A, Hankovszky P, Molnár T, Szabó Zs, Babik B. [Diagnostic consideration and bedside estimation of the prognosis in COVID-19 patients]. Orv Hetil. 2020; 161(17): 667-671.

(Beérkezett: 2020. március 27.; elfogadva: 2020. március 30.)

\begin{abstract}
Rövidítések
APTI = aktivált parciális tromboplasztinidő; $\mathrm{BAL}=$ bronchoalveolaris lavage; $\mathrm{CMV}=$ cytomegalovirus COVID $-19=($ coronavirus disease 2019) koronavírus-betegség 2019; CT = (computed tomography) számítógépes tomográfia; EBV = Epstein-Barr-vírus; $\mathrm{H}_{1} \mathrm{~N}_{1}=$ a hemagglutinin l-es és a neuraminidáz l-es típusát tartalmazó vírus; HSV = herpes simplex virus; $\mathrm{LDH}=$ laktátdehidrogenáz; MERS $=($ Middle East respiratory syndrome) közel-keleti légzési szindróma; $\mathrm{pH}=$ pondus hidrogenii; $\mathrm{pCO}_{2}=$ (partial pressure of carbon dioxide) a széndioxid parciális nyomása; $\mathrm{PCR}=$ (polymerase chain reaction $)$ polimeráz-láncreakció; RNS = ribonukleinsav; RS-vírus = respiratory syncytial virus; RT-PCR $=$ (real-time reverse transcriptase polymerase chain reaction) valós idejü reverztranszkriptáz PCR; SARS-CoV = (severe acute respiratory syndrome coronavirus) heveny akut légzési szindrómát okozó koronavírus; SARS-CoV-2 $=$ (severe acute respiratory syndrome coronavirus 2) SARS-koronavírus-2; SOFA = (sequential organ failure assessment) a szervi elégtelenség súlyossági pontrendszere; WHO $=$ (World Health Organization) Egészségügyi Világszervezet
\end{abstract}

A COVID-19 diagnózisa felállításának alapvető eleme a 'real-time' reverztranszkriptáz polimeráz-láncreakció (RT-PCR), melynek specificitása $100 \%$. A vizsgálat azonban esetlegesen fals negatív eredményeket produkálhat, mert a vírusnak $\mathrm{kb}$. 5 napra van szüksége a vizsgálat pozitivitásához elegendő kópia kialakulásához. Rontja a szenzitivitást az a tény is, hogy fertőzés és mintavétel is lokalizálódhat az alsó és felső légutakra egyaránt. Ilyenkor a klinikai tünetek és az epidemiológiai kapcsolat felderítése segíthet. A fertőzés korai, tünetmentes szakaszában adott esetben csak ez utóbbi hordoz diagnosztikus értéket. Összességében a fertőzést megelőző időszak epidemiológiai kapcsolatai, a tünetek és a RT-PCR együttese egyaránt szükséges lehet a biztos és pontos diagnózis felállításához.

\section{Epidemiológiai kapcsolat}

A korábbi SARS-járvány kapcsán Kínában egy „ismeretlen eredetú pneumonia" 'surveillance' csoportot hívtak életre azzal a céllal, hogy az új patogének felismerése mindenkor időben megvalósulhasson. Ezen epidemiológiai és infektológiai felderítőrendszer segítségével derült fény arra, hogy a helyi kórházak által 2019. december 29-ig jelentett négy tisztázatlan etiológiájú pneumoniás beteg mindegyike szorosan köthető egy vadhúspiachoz
(Huanan Seafood Wholesale Market) [1-3]. Ennek megfelelően az esetdefiníció eredetileg az alábbi elemekből állt: láz, radiológiai jeleket is mutató pneumonia, alacsony vagy normális fehérvérsejtszám, alacsony lymphocytaszám $\left(<1 \times 10^{9} / 1\right)$ és szoros kontaktus a Huanan piaccal vagy hasonló tüneteket mutató beteggel.

Az esetek száma növekedett, az epidemiológiai és klinikai ismeretek pedig szélesedtek, így 2020. január 18-án már módosítottak az esetdefiníción: a gyanított esetek köre azokra vonatkozott, akik légúti tünetekkel jelentkeztek (láz, nehézlégzés, száraz köhögés), és a tünetek fellépésének kezdete előtt 14 napon belül Wuhanban jártak, illetve ott járt személlyel kerültek közeli kapcsolatba [3].

Az aktív nemzetközi személyforgalom hatásaként a fertőzés más országokba is hamar eljutott, először ázsiai országokba (Dél-Korea, Japán, Szingapúr, Hongkong és Irán), majd európai országokba is, melyek gócpontját Olaszország északi régiói (Veneto, Lombardia, Piemonte, Emilia-Romagna tartományok) képezték. Az esetdefiníció utazási anamnézisre vonatkozó epidemiológiai kitétele ennek megfelelően szélesedett. A járvány pandémiává vált [4], feltartóztathatatlanul eljutott a Föld minden országába. A Nemzeti Népegészségügyi Központ jelen napjainkban érvényes, a WHO-esetdefinícióján alapuló esetdefiníciója alapján COVID-19-gyanúsnak minősülnek az „Eljárásrend a 2020. évben azonosított új koronavírussal kapcsolatban" címú tájékoztatóban felsorolt feltételeknek megfelelő személyek [5]. Látható, hogy az utazási anamnézis jelentősége csökkent, míg az igazoltan fertőzöttel történő kontaktus jelentősége nőtt. Az utóbbi csoporthoz tartozik a megfertőződött egészségügyi ellátók nagy része is [6]. A lakosság átfertőzöttsége nagy és növekvő, ugyanakkor - elsősorban az enyhe és szubklinikus - esetek java labordiagnosztikával nincs megerősítve, így az ,igazoltan fertőzött beteggel történő szoros kontaktus" is kevésbé értelmezhető. Emiatt a tisztázatlan eredetű, súlyos pneumoniával és következményes légzési elégtelenséggel kórházi ellátásra szoruló betegek is gyanús esetnek számíthatnak, különös tekintettel a kritikus állapotú betegekre $[5,7]$.

\section{Klinikai tünetek}

Az első leíró közlemények Kínából 2020. január végén kezdtek megjelenni. Ezek szerint a COVID-19 leggyakoribb klinikai tünetei közé a láz, az általános gyengeség és a száraz köhögés sorolható, melyeket gyakoriság sze- 
rint az izomfájdalom, a nehézlégzés, a fejfájás, a szédülés követ, és ritkábban hasi panaszok (hasfájás, hasmenés, hányinger) is előfordulnak. A tünetek tehát nem különböznek más felső légúti fertőzések tüneteitől; specifikus tünete vagy jele pedig egyáltalán nincs.

A lázat a legtöbb tanulmányban $37,5^{\circ} \mathrm{C}$ feletti testhőmérsékletként definiálták. Az adatok a láz előfordulási frekvenciájában eltérőek: van olyan közlemény, melyben láz csak 43,8\%-ban volt a felvételkor [8], ám a többi cikk ennél nagyobb arányszámot közöl [6]. Összességében azonban a láztalanság nem zárja ki a SARS-CoV-2 vírus okozta infekció fennállását: elég csak arra gondolnunk, hogy a fertőzöttek zöme teljesen tünetmentes, azaz láztalan. Ugyanakkor azt is látjuk az eddigi adatokból, hogy a láz jelenléte, illetve a magas láz súlyosabb kórlefolyást valószínúsít $[3,6,8]$. Az atípusos tünetek is félrevezetők lehetnek. Leírásra került egy olyan eset is, mikor a betegnek kizárólag hasi tünetei voltak, és emiatt sebészeti osztályra került. Pár nap múltán végül COVID-19 igazolódott. Ekkorra a beteg a sebészeti osztályos bennfekvése során 10 egészségügyi dolgozót fertőzött meg SARSCoV-2-vel [6]. Az atípusos hasi tünetek aránya valószínúleg magasabb, mint azt a járvány elején gondolták. Egy 204 beteg adatait elemző leíró tanulmány szerint az abdominalis tünetek 48,5\%-ban voltak jelen, és a kimenetelük is kedvezötlen volt [9].

Összességében a jelenleg rendelkezésre álló adatok szerint a három vezető tünetnek az alábbiakat tartjuk: láz, köhögés és légszomj, és ezek legalább egyikének a jelenléte a diagnosztikus folyamatot is segíti [5].

A legtöbb beteg sürgősségi osztályon jelentkezik, ahol megtörténik az anamnézis felvétele, a fizikális vizsgálat, a rutin-labordiagnosztika és szükség esetén az alapvető képalkotó vizsgálat. Az így nyert információk és adatok egyike sem specifikus a COVID-19-re, éppen ezért nem is diagnosztikus kritériumok. Ugyanakkor bizonyos paraméterek utalhatnak arra, hogy kik azok a betegek, akiknél várhatóbb a súlyos kórlefolyás. Ezeket az adatokat a „Prognosztika” fejezetben részletezzük.

\section{Mikrobiológiai diagnosztika}

A klinikusi hozzáállás nem különbözhet tulajdonképpen a korábbiaktól: ha a betegnek légzési elégtelenséget okozó súlyos pneumoniája van, minden esetben törekszünk a kiváltó ágens azonosítására. Mivel a COVID-19-nek specifikus tünete nincs, és a klinikum jelentős átfedést mutat más súlyos légúti fertőzésekkel, többféle kórokozó kizárása egyidejúleg szükséges. A mikrobiológiai mintavételezést az antimikrobás szerek indítása előtt kell elvégezni, és ennek tartalmaznia kell a standard mintavételeket:

- két pár szúrt hemokultúra; vizeletból bakteriológia + Legionella-antigén + Streptococcus-antigén meghatározása;

- nem intubált beteg esetében garattörlésből/intubált beteg esetében tracheaaspirátumból: bakteriológia +
RS-vírus-PCR + adenovírus-PCR + szezonálisan influenza-PCR;

- szezonálisan atípusos baktériumok - Legionella, Mycoplasma, Chlamydia-PCR-e alsó légúti mintából, intubált beteg esetén / antitest-szerológia, nem intubált beteg esetén;

- immunszupprimált beteg esetében kiegészítés: légúti és szérum-CMV, -EBV, -HSVl/2 PCR-e és gombadiagnosztika: galaktomannán-antigén alsó légúti mintából, galaktomannán-antigén + 1,3-béta-D-glükán szérumból [10].

Mindezek mellett a jelenlegi pandémia miatt a SARSCoV-2 PCR-vizsgálatát is el kell végeztetni.

\section{'Real-time' RT-PCR}

A SARS-CoV-2 kimutatásának arany standardja a 'real-time' reverztranszkriptáz polimeráz-láncreakció (RT-PCR). A COVID-19 diagnosztikai kihívást jelent a hosszú (kb. kéthetes) inkubációs periódus miatt, melynek része egy kb. ötnapos vírusürítési fázis is, mely a tünetek fellépését megelőzi. A vírus a felső és/vagy az alsó légúti traktusban egyaránt szaporodhat, ez egyénenként különböző lehet, és a minta eredményét befolyásolhatja $[6,11,12]$.

A fertőzöttséget a pozitív SARS-CoV-2-PCR definiálja. Akinek tünete van, az COVID-19-ben szenvedő beteg. Aki teljesen tünetmentes, az SARS-CoV-2-fertőzött. A tünetmentes fertőzöttek frekvenciája a populációban ismeretlen, arányuk az összes fertőzött 81\%-ára becsülhető.

\section{Mintavétel}

Nem intubált beteg esetében a mintavétel garatváladékból történik. Oropharyngealis és nasopharyngealis váladékból egyaránt nyerhető minta. Fontos, hogy megfelelő mennyiségú sejtet nyerjünk a mintavétel során, mivel abból a potenciálisan pozitív eredmény kinyerése valószínúbb. A mintavétel során a vírus transzporttáptalajos mintavevő csőhöz rendelt sörtés - azaz megnagyított felszínú - mintavevő pálcát használjunk, melyet kb. 10 mp-ig kell a garatfalhoz nyomva óvatosan forgatni, majd a pálcát a megjelölt helyen a transzporttáptalajba kell beletörni. Spontán köpetürítés esetén a köpetvizsgálat hasznos lehet, de a köpet indukálása kerülendő, a fokozott aeroszolképződés miatt.

Intubált beteg esetében alsó légúti mintavétel javasolt. A tracheaaspirátum megfelelő alsó légúti minta. A bronchoalveolaris lavage (BAL) levétele, illetve a bronchusmosás kerülendő, mert szintén fokozott aeroszolképződéssel járhatnak [13]. Intubált beteg esetében a tracheaváladék mellett felső légúti mintavételezés nem szükséges. Amikor csak lehet, alsó légúti minta vizsgálata javasolt, melynek szenzitivitása magasabb a felső légúti minta vizsgálatánál. 


\section{A RT-PCR-eredmény értelmezése}

A RT-PCR alapvetően magas szenzitivitású és specificitású vizsgálat [14]. A felső légúti minta feldolgozása során fals pozitív eredményt eddig nem detektáltak, azaz a specificitás $100 \%$. Negatív prediktív értéke azonban alacsonyabb, a szenzitivitást $65-70 \%$ körülire becsülik $[15,16]$.

A pozitív RT-PCR-eredmény megerősíti a SARSCoV-2-fertőzöttséget.

Negatív RT-PCR-eredmény esetén, amennyiben a negatív eredmény mellett a klinikai gyanú megalapozottan fennáll, a COVID-19 diagnózisa nem vetendő el, hanem javasolt a vizsgálat megismétlése 48 óra múlva [17, 18]. Ha mindkét minta negatív eredményü, a fertőzés kizárható [5].

Egy német közlemény szerint a csúcs-RNS-koncentrációt már a fertőződés 5 . napja előtt eléri, így a pozitív eredmény, mi több a sikeres vírusizoláció is jóval magasabb a jelen járványban, mint a SARS-ban [12]. Mindez a felső légúti aktív vírusreplikáció mellett szól, s ebben a tanulmányban a felső légúti minta érzékenységét is megfelelően magasnak találták. Az önálló felső légúti vírusreplikáció és vírusürítés a SARS-CoV-2 magas contagiositasát is támogatja. Az alsó légúti aktív vírusreplikáció hasonló, mint a SARS-CoV esetén, így az alsó légúti minta PCR-vizsgálata hasonlóan magas szenzitivitású. Mindemellett a magas széklet-RNS-koncentráció alapján aktív replikáció valószínúsíthető a gastrointestinalis traktusban is, mely egyébként a SARS-CoV-hoz hasonló jelenség, viszont különbözik a MERS-től.

A vírusürítés két hétig valószínú. A seroconversio már a második héten általában megtörténik, de nem jár együtt a vírusürítés rapid csökkenésével. Fontos kérdés, hogy a beteg meddig fertőzőképes, illetve mikor végezzünk kontrollteszteket. A teszt egy ideig még pozitív maradhat a klinikai gyógyulást követően is. A fenti német tanulmány szerint, ha a magas betegszám miatt különös nyomás nehezedik a kórházakra, és a klinikailag már jó állapotú beteg mielőbbi hazabocsátása preferált, akkor a 10. napon túl - ha a köpetben a vírus $<100000$ RNS-kópiaszám/ml koncentrációban van jelen - a fertőzőképesség valószínűsíthetően már alacsony, és otthoni karanténba a beteg hazabocsátható [12]. A jelenlegi magyar szabályozás szerint a gyógyult beteg elbocsátásához minimum 24 óra különbséggel levett, 3 negatív eredményű légúti minta szükséges. Az első felszabadító mintát a betegtől a tünetek kezdetét követően legalább 7 nappal vagy a láz megszúnése után legalább 3 nappal kell levenni [5].

\section{Prognosztika}

Amennyiben a SARS-CoV-2 vírus okozta fertőzés RT-PCR-rel megerősítésre került, és a betegnek az 1 . pontban részletezett tünetei is vannak, járványosztályra kerül, az eleve kritikus állapotban érkező betegek pedig a járványkórház intenzív osztályára. Kérdés azonban, hogy hogyan tudjuk időben felismerni azokat a betegeket, akiket a rapid állapotromlás veszélye fenyeget.

Kínai adatok szerint az összes COVID-19-beteg 5\%-a került intenzív osztályra. Olaszországban a pozitív esetek 12\%-a került kritikus állapotba, ami a kórházban kezelt COVID-19-betegek 16\%-át jelentette [19].

Több kínai közlemény igen magas mortalitási adatokat közöl az intenzív terápiára és ijesztően magas halálozási arányokat (81-97\%!) a gépi lélegeztetésre szoruló betegek körében $[20,21]$.

A betegek iniciális (általában sürgősségi osztályos) vizsgálatakor számtalan információhoz jutunk az anamnézisfelvétel, a statusvizsgálat, a rutinlaborok, vérgázvizsgálat és a képalkotó vizsgálatok által. A magas rizikójú betegek kiszűrésében az eddigi adatelemzések segíthetnek, melyek a súlyos (azaz intenzív osztályos kezelésre szoruló betegek) és a nem súlyos (járványosztályon kezelhető) betegek karakterisztikáját hasonlították össze [6].

Az egyik első leíró közlemény egy viszonylag homogén populációról tájékoztat, amelynél a megbetegedettek 66\%-a közvetlenül a Huanan piaccal volt kapcsolatban. A közlemény 41 betegének jelentős része átlagosan 49 éves, zömében (a piacon dolgozó) férfi volt, és csak harmaduknak volt valamilyen társbántalmuk.

A későbbi közlemények adatai ettől némileg eltérő arányokat tükröznek $[6,8,19,22]$. Az összességében néhány ezres analizált betegpopuláció adataiból az derül ki, hogy súlyos betegségre számíthatunk az idősebb korosztályban [3, 20-22], bár a fiatalabbak sem védettek ez ellen. A kínai tanulmányok zömében a súlyos betegek átlagéletkora 52-66 év [6, 8, 21]. Az olasz populációban a fatális esetek aránya (case fatality ratio) az életkorral nő, 70 év felett 12\%, 80 év felett 20\% [22]. A társbetegségek (hypertonia, diabetes mellitus, cardiovascularis megbetegedés stb.) is gyakoribbak a súlyos állapotúak körében $[6,8,21]$. A férfiak (súlyos és kevésbé súlyos állapotúak) aránya valamivel nagyobb, mint a nóké $[6,8,22]$. A dohányzó betegek aránya nagyobb volt a progrediáló kórlefolyásúak között [3].

A statusfelvétel során észlelt magasabb (>38 ${ }^{\circ} \mathrm{C}$-os) láz, az elesettebb általános állapot, a magas légzésszám szintén magas rizikót jelentett $[3,6,8]$. A laborparaméterek közül rossz prognózisra utal a lymphopenia $(<1 \times$ $\left.10^{9} / 1\right)[6,8,16]$, ebben a legtöbb tanulmány egyetért. $X i e$ és mtsai adatai szerint a súlyos lymphopenia és az emelkedett CRP-szint korrelál a hypoxaemia súlyosságával és a várható kórházi mortalitással. A lymphocytaszám csökkenését is érdemes a kórházi felvételt követő első 4 napban követni [16]. Az emelkedett CRP-, transzamináz-, LDH-szint, APTI, az alacsony albuminszint és thrombocytaszám is rossz prognosztikai jel, csakúgy, mint a vérgázparaméterek által tükrözött parciális vagy globális légzési elégtelenség [3]. A megfigyelések szerint a hypoxiás légzési elégtelenség gyakoribb, mint a globá- 
lis, azaz a betegek hypoxiásan, de még normális $\mathrm{pH}$-val és $\mathrm{pCO}_{2}$-szinttel kerülnek felvételre az intenzív osztályra.

A radiológiai vizsgálatok során, a mellkasröntgenen és/vagy CT-képen észlelt eltérések súlyossága, a kiterjedtebb légtartalom-csökkenés, valamint a pleuralis fluidum jelenléte is kedvezőtlen prognosztikai jel [8].

A legutóbbi olasz adatok szerint a COVID-19-betegek közel 30\%-a súlyos, azon belül 5\%-uk kritikus állapotú [22]. A kórkép progressziója lassabb, mint a $\mathrm{H}_{1} \mathrm{~N}_{1}$ esetében volt, azaz a légzési elégtelenség kifejlődéséig eltelt átlagos időtartam több mint 7 nap, és ezt megelőzően általában más szervdiszfunkció sem lép fel. Mindezek miatt sem a SOFA-, sem a NEWS-pontrendszer nem alkalmas azon betegek kiszürésére, akiknek az állapota várhatóan romlik [17]. Jelenleg nincs olyan biomarker, mely egyértelmüen segítségünkre volna a nagy rizikójú betegek korai felismerésében.

Anyagi támogatás: A szerzők a kézirat elkészítéséért anyagi támogatásban nem részesültek.

Szerzői munkamegosztás: K. A., K. Sz., L. A., H. P., M. T., Sz. Zs., B. B. az irodalomgyưjtésben és az egyes alfejezetek elókészítésében vett részt. A cikk végleges változatát valamennyi szerző elolvasta és jóváhagyta.

Érdekeltségek: A szerzők a kézirat elkészítésében pénzügyi vagy egyéb személyes érdekeltséggel nem rendelkeztek.

\section{Irodalom}

[1] Li Q, Guan X, Wu P, et al. Early transmission dynamics in Wuhan, China, of novel coronavirus-infected pneumonia. N Engl J Med. 2020; 382: 1199-1207.

[2] Liu Y, Li J, Feng Y. Critical care response to a hospital outbreak of the 2019-nCoV infection in Shenzhen, China. Crit Care $2020 ; 24: 56$.

[3] Liu W, Tao ZW, Lei W, et al. Analysis of factors associated with disease outcomes in hospitalized patients with 2019 novel coronavirus disease. Chin Med J (Engl). 2020 Feb 28. Doi: 10.1097/ CM9.0000000000000775. [Epub ahead of print]

[4] Cucinotta D, Vanelli M. WHO declares COVID-19 a pandemic. Acta Biomed. 2020; 91: 157-160.

[5] National Public Health Center. [Nemzeti Népegészségügyi Központ. Eljárásrend a 2020. évben azonosított új koronavírussal kapcsolatban. 2020. március 18.] NNK, Budapest. Available from: https://www.nnk.gov.hu/index.php/component/content/article/140-koronavirus-tajekoztatok/567-eljarasrend-a2020-evben-azonositott-uj-koronavirussal-kapcsolatban-202003-16? Itemid=135 [accessed: 25 March 2020]. [Hungarian]

[6] Wang D, Hu B, Hu C, et al. Clinical characteristics of 138 hospitalized patients with 2019 novel coronavirus-infected pneumonia in Wuhan, China. JAMA 2020; 323: 1061-069.

[7] Centers for Disease Control and Prevention. Coronavirus Disease 2019 (COVID-19). CDC, Atlanta, GA, 2020 March 21.
Available from: https://www.cdc.gov/coronavirus/2019-ncov/ hcp/therapeutic-options.html.

[8] Guan WJ, Ni ZY, Hu Y, et al., for the China Medical Treatment Expert Group for Covid-19. Clinical characteristics of coronavirus disease 2019 in China. N Engl J Med. 2020 Feb 28. Doi: 10.1056/NEJMoa2002032. [Epub ahead of print]

[9] Pan L, Mu M, Yang P, et al. Clinical characteristics of COVID-19 patients with digestive symptoms in Hubei, China: a descriptive, cross-sectional, multicenter study. Available from: https://journals.lww.com/ajg/Documents/COVID_Digestive_Symptoms_ AJG_Preproof.pdf.

[10] Standard microbiological sample protocol at University of Szeged, Hungary. [Szegedi Tudományegyetem. Standard mikrobiológiai mintavételezési protokoll.] Available from: [accessed: http://www.klinikaikozpont.u-szeged.hu/aiti/hu/intezetiprotokollok.html]. [Hungarian]

[11] Linton NM, Kobayashi T, Yang Y, et al. Incubation period and other epidemiological characteristics of 2019 novel coronavirus infections with right truncation: a statistical analysis of publicly available case data. J Clin Med. 2020; 9: 538.

[12] Wölfel R, Corman VM, Guggemos W. Clinical presentation and virological assessment of hospitalized cases of coronavirus disease 2019 in a travel-associated transmission cluster. medRxiv 2020 Mar 8. Doi: https://doi.org/10.1101/2020.03.05.20030502.

[13] Bouadma L, Lescure FX, Lucet JC, et al. Severe SARS-CoV-2 infections: practical considerations and management strategy for intensivists. Intensive Care Med. 2020; 46: 579-582.

[14] Corman VM, Landt O, Kaiser M, et al. Detection of 2019 novel coronavirus (2019-nCoV) by real-time RT-PCR. Euro Surveill. 2020; 25: 2000045. Doi: 10.2807/1560-7917.ES.2020.25.3. 2000045

[15] Yam WC, Chan KH, Poon LL, et al. Evaluation of reverse transcription-PCR assays for rapid diagnosis of severe acute respiratory syndrome associated with a novel coronavirus. J Clin Microbiol. 2003; 41: 4521-4524.

[16] Xie J, Tong Z, Guan X, et al. Critical care crisis and some recommendations during the COVID-19 epidemic in China. Intensive Care Med. 2020 Mar 2. Doi: 10.1007/s00134-020-05979-7. [Epub ahead of print]

[17] Arabi YM, Murthy S, Webb S. Correction to: COVID-19: a novel coronavirus and a novel challenge for critical care. Intensive Care Med. 2020 Mar 18. 1-2. Doi: 10.1007/s00134-02006009-2. [Epub ahead of print]

[18] European Centre for Disease Prevention and Control. Coronavirus disease. ECDC, Solna, 2020 March. Available from: https:// www.ecdc.europa.eu/en.

[19] Grasselli G, Pesenti A, Cecconi M. Critical care utilization for the COVID-19 outbreak in Lombardy, Italy: early experience and forecast during an emergency response. JAMA 2020 Mar 13. Doi: 10.1001/jama.2020.4031. [Epub ahead of print]

[20] Zhu N, Zhang D, Wang W, et al. A novel coronavirus from patients with pneumonia in China, 2019. N Engl J Med. 2020; 382: 727-733

[21] Yang X, Yu Y, Xu J, et al. Clinical course and outcomes of critically ill patients with SARS-CoV-2 pneumonia in Wuhan, China: a single-centered, retrospective, observational study. Lancet Respir Med. 2020 Feb 24. Doi: 10.1016/S2213-2600(20) 30079-5. [Published correction: Lancet Respir Med. 2020 Feb 28.] [Epub ahead of print]

[22] Livingston E, Bucher K. Coronavirus disease 2019 (COVID-19) in Italy. JAMA 2020 Mar 17. Doi: 10.1001/jama.2020.4344. [Epub ahead of print]

(Babik Barna dr., Szeged, Semmelweis u. 6., 6720 e-mail: babikbarna@gmail.com)

A cikk a Creative Commons Attribution 4.0 International License (https://creativecommons.org/licenses/by/4.0/) feltételei szerint publikált Open Access közlemény, melynek szellemében a cikk bármilyen médiumban szabadon felhasználható, megosztható és újraközölhetö, feltéve, hogy az eredeti szerző és a közlés helye illetve a CC License linkje és az esetlegesen végrehajtott módosítások feltüntetésre kerülnek. (SID_1) 